\title{
Formy niewerbalne w produkcjach filmowych w perspektywie wybranych koncepcji komunikowania społecznego
}

\begin{abstract}
Streszczenie
Tak zwane nowe media redefiniują relacje społeczne w mikro- i makrowymiarze. Użytkownik mediów sprzed pięciu czy sześciu dekad i użytkownik współczesny to dwa różne podmioty. W ciąg pół wieku zmieniły się funkcje poszczególnych mediów, ich rola w społeczeństwie, a tym samym wzorce percepcji użytkowników. Odbiorca z początku XXI wieku jest zupełnie inaczej wyposażony antropologicznie niż jego medialny antenat w latach 60 . minionego stulecia.

Niemniej rzecz pozostaje bez istotnych zmian, zarówno w świecie realnym, jak i kreowanym przez media. W obu mamy do czynienia z uprzywilejowaną pozycją wzroku i słuchu, zaś smak, węch i dotyk pozostają na obrzeżach uwagi, chociaż odpowiadające im wrażenia też są powszechne.

W artykule skupiam uwagę przede wszystkim na zmyśle węchu, ale też ściśle z nim powiązanym zmyśle smaku. Zapach jako zbyt ulotny i nieokreślony, niedający się mierzyć w takim stopniu jak dźwięk czy obraz, ustępuje pola zmysłom bardziej trwałym i jednoznacznym. Obecność zapachu w produkcjach filmowych należy uznać za skrajnie marginalną, co związane jest, jak sądzę, głównie z możliwościami technologicznymi, czy też raczej z ich brakiem w tym zakresie.
\end{abstract}

1 Urszula Kusio, Wydział Filozofii i Socjologii, Uniwersytet Marii Curie-Skłodowskiej, Polska, e-mail: urszula.kusio@poczta.umcs.lublin.pl, ORCID ID: https://orcid.org/0000-0002-8938-7111. 
Stawiam w tekście tezę, iż pewne filmy winno oglądać się nosem i kubkami smakowymi, przez co stają się one źródłem poznawczego pogubienia, bowiem ich istotne cechy są poza zasięgiem zmysłowym odbiorcy. W trakcie analizy filmowych przykładów nabieram przekonania, iż filmowy realizm (ale nie tylko realizm) wymaga polisensoryczności, w przeciwnym razie mamy do czynienia z epistemiczną schizofrenią.

Powyższy namysł został podjęty w kontekście dwóch teorii komunikowania społecznego: klasycznej propozycji M. McLuchana oraz kognitywnej teorii filmu.

\title{
Słowa kluczowe:
}

media, film, zapach, zmysły, komunikacja

\begin{abstract}
The so-called new media redefine social relations both on a micro and a macro scale. A media user from five or six decades ago is an entirely different subject to a modern user. Within half a century, the roles of particular media, their social functions, and consequently users' patterns of perception all changed. A $21^{\text {st }-c e n t u r y ~ r e c i p i e n t ~ i s, ~ a s ~ f a r ~ a s ~ a n t h r o p o l o g y ~ i s ~ c o n c e r n e d, ~ e q u i p p e d ~}$ totally differently to one from the 1960s.

Nevertheless, one thing remains unchanged in the real and the media worlds alike. Both confront us with the predominance of sight and hearing while taste, smell, and touch are of peripheral interest in spite of the perceptions conveyed through them being all-encompassing.

The article focuses primarily on the sense of smell, but also on the closely related taste. Smell is too elusive and indeterminate and cannot be measured to the same extent sound is measured, for instance. Smell therefore has to give way to the more durable and definite senses. Its presence in films is absolutely marginal which is due to, as I perceive it, the technological capabilities in this area, or rather lack thereof.

In this text I argue that certain films should be watched with one's nose and taste buds, are a source of cognitive confusion, since everything important depicted in them is beyond the viewer's reach. When scrutinising such films, one arrives at a conclusion that cinematic realism (but not only realism) must be multisensory. Otherwise, a case of epistemic schizophrenia occurs.

The above reflection is undertaken in the context of two theories of social communication, namely M. McLuhan's classic proposal and the cognitive theory of film.
\end{abstract}

\section{Keywords:}

media, film, smell, senses, communication 


\section{TEORETYCZNE RAMY ROZWAŻAŃ}

Komunikowanie jest zgodnie uznawane za fundament życia społecznego, z tego też powodu bywa przedmiotem badań przedstawicieli wielu dyscyplin. Współcześnie naukową refleksję nad zagadnieniami komunikowania radykalnie zmienił i zintensyfikował rozwój mediów elektronicznych. Zaburzona została klasyczna relacja nadawca-odbiorca. Pojawiły się przekaźniki interaktywne wykorzystujące wysokorozwinięte technologie, które nie tylko nieodwracalnie zmieniły kulturowo-medialną rzeczywistość, ale też wywarły trwałe skutki antropologiczne.

Użytkownik mediów sprzed pięciu, sześciu dekad i użytkownik współczesny to dwa różne podmioty. W ciągu pół wieku zmieniły się funkcje poszczególnych mediów, ich rola w społeczeństwie, a tym samym wzorce percepcji użytkowników. Odbiorca z początku XXI wieku jest zupełnie inaczej wyposażony antropologicznie niż jego medialny antenat w latach 60 . minionego stulecia. Badaczka mediów Maryla Hopfinger (2003) podkreśla: „Każda epoka z siłą przymusu kulturowego modeluje wyposażenie antropologiczne swoich uczestników. Ukształtowanie typu kulturowego sprzyja bowiem określonej strukturze preferencji w odbiorze; nakierowuje kodowanie na pewne tylko obszary oraz wymiany realności: tworzy rodzaj filtru, poprzez który każe swoim uczestnikom postrzegać świat i konstruować znaczenia. Wywiera trwałe skutki antropologiczne; wpływa na percepcję, która jest oczywiście funkcją doświadczenia i wiedzy” (s. 10). Oznacza to, że rzeczywistość widziana oczami współczesnego odbiorcy znacznie różni się od tej z czasów dominacji druku i to nie tylko z powodu faktycznych zmian w wyglądzie otoczenia, ale także za sprawą zmienionych skryptów percepcji patrzącego. W nowej przestrzeni inaczej funkcjonują stare media, zmienia się ich wpływ i siła oddziaływania na odbiorcę.

Warto już na wstępie podkreślić, iż podział na stare i nowe media jest nieostry i niejednoznaczny. Wyrażenie „nowe media” jest w użyciu od lat 60. XX wieku i objęło swoim zakresem stale rozszerzający się i różnicujący zbiór stosowanych technologii komunikacyjnych. Tradycyjne media były zasadniczo jednokierunkowe, podczas gdy nowe cechuje wzajemne powiązanie, dostęp dla indywidualnych użytkowników występujących w charakterze nadawców lub odbiorców, interaktywność, wielość sposobów użycia i otwartość, jak również wszechobecność, niedookreśloność przestrzenna i delokalizacja (McQuail, 2007, s. 57).

Można też nowe media pojmować przez pryzmat filozofii Jeana Baudrillarda. Wówczas nowe media to te, które produkują obrazy całkowicie zsyntetyzowane, czyli obrazy komputerowe nieposiadające swoich analogonów, niepotrzebujące rzeczywistości. One są samowystarczalne, symulacja rzeczywistości przeradza 
się w rzeczywistość symulacji. Obraz generowany elektronicznie jest całkowicie autoreferencyjny, jego jedynym kontekstem może być tylko to, co go poprzedza (obraz uprzedni), i to, co następuje po nim (kolejny obraz).

Kulturowo-medialna teraźniejszość najczęściej rozpatrywana jest i ujmowana w kluczu audiowizualności i/lub tzw. audiowizualnego syndromu w percepcji. Czasem jednak pomija się niezwykle istotny aspekt. Otóż w dzisiejszej przestrzeni komunikacyjnej funkcjonują równolegle (a może raczej - obok siebie) dwa typy audiowizualności. Pierwszy - nazwijmy go roboczo klasycznym - czasowo wcześniejszy, rozwijał się pod wpływem analogowego obrazu fotograficznego, kina, a później także komunikacji telewizyjnej. Drugi typ to tzw. audiowizualność symulacyjna (elektroniczna audiowizualność multimedialna) „rozwijająca się na podglebiu i zapleczu audiowizualności wcześniejszej, powołuje zintegrowany, pulsujący bogactwem informacji, funkcjonalnie zrównoważony, kolorowy i stereofoniczny obrazodźwięk” (Hopfinger, 2003, s. 30).

Można to ująć w następujący sposób: część odbiorców funkcjonuje w ramach klasycznej percepcji audiowizualnej, część zaś jest już na etapie wizualności symulacyjnej, a kryterium podziału byłby tu zwłaszcza dostęp do komputera i sieci oraz oczywiście umiejętność posługiwania się nimi. Na poziomie odbiorczym rozłam między obiema grupami jest duży. Członkowie pierwszej mogą reprezentować aktywną (krytyczną) lub pasywną (bezrefleksyjną) formę odbioru przekazów. Kompetencje komunikacyjne zależą tu od wykształcenia, inteligencji, a także - oględnie mówiąc - obycia w zakresie komunikacji medialnej i chęci do podjęcia odbiorczej aktywności. Z kolei osoby cechujące się percepcją elektroniczną reprezentują zawsze i wyłącznie krytyczną postawę odbiorczą. To użytkownicy komputera i sieci, dla których interaktywność jest integralną i oczywistą częścią procesu komunikacji. Wystąpienia komunikacji zwrotnej i stała wymiana funkcji na linii nadawca-odbiorca wymusza stałą odbiorczą uwagę i aktywność. Interaktywność w przypadku starszych mediów, na przykład prasy (listy do redakcji, wypowiedzi na antenie), jest wprawdzie możliwa, ale też podlega istotnym ograniczeniom. Ze skrajnie odmienną sytuacją mamy do czynienia w przypadku komunikacji za pośrednictwem komputera i sieci. Jak słusznie zauważa Hopfinger (2003): „Układ komputer-użytkownik ma w pełni interaktywny charakter, wymaga stosunków partnerskich, wzajemnej wymiany informacji, obustronnej aktywności komunikacyjnej. Tu jest się przemiennie odbiorcą i nadawcą. Bierny odbiór nie jest w tym układzie możliwy. Stąd też charakterystyczna zmiana kategorii odbiorcy na kategorię użytkownika. [...] Użytkownik komputera z założenia aktywnie współtworzy komputerowy tekst. Tym samym zostaje podważony tradycyjny podział ról na nadawcę i odbiorcę, na autora i odbiorcę, a zapewnia ich wymienność” (s. 28). 
Zatem dynamiczny rozwój technologii informacyjnych, będących znakiem obecnych czasów, przyczynia się do skokowej zmiany w relacjach komunikacyjnych między ludźmi. Zasięg tych zmian tak znacząco determinuje sposób funkcjonowania współczesnego człowieka we wszystkich sferach jego aktywności, że obecne czasy zgodnie określane są mianem cywilizacji informacyjnej. Tendencje rozwoju tego etapu cywilizacyjnego, jego właściwości strukturalne i funkcjonalne są zazwyczaj opisywane niejako in statu nascendi. Technologie medialne bowiem tworzą nową jakość rzeczywistości w sposób najczęściej niezauważalny, zgodnie ze słowami, które można przeczytać u Marshalla McLuhana (2001): „ryby nie wiedzą, że woda istnieje, póki nie zostaną wyrzucone na brzeg” (s. 57).

Cokolwiek jednak zostałoby powiedziane o starych i nowych mediach, o ich nadawcach i odbiorcach, o ich aktywności bądź pasywności, o ich ewolucyjnych lub rewolucyjnych zmianach, to niezmienny pozostaje fakt, iż bazują one wciąż i niezmiennie na dwóch zmysłach - wzroku i słuchu.

Wprowadzony przez Arystotelesa klasyczny już podział na pięć zmysłów: wzrok, słuch, dotyk, smak i węch, na dobre zadomowił się w myśleniu naukowym i potocznym. Jest jednak wiele argumentów za tym, że zwłaszcza wzrok odgrywa wyróżnioną rolę w naszym doświadczeniu świata. W epistemologii percepcja to tyle, co spostrzeganie zmysłowe i zgodnie ze swoją łacińską etymologią oznacza pojmowanie, poznanie, postrzeganie, znajomość i zrozumienie. Może dlatego większość przykładów dotyczących percepcji jako problemu filozoficznego związana jest ze spostrzeganiem zmysłowym. Mamy też optykę, część fizyki, zajmującą się między innymi przyrodniczym aspektem widzenia. Podobną rolę odgrywa akustyka, zajmująca się dźwiękami, a przez to dostarczająca wiele materiału do analizy spostrzeżenia słuchowego, aczkolwiek nie jest ono tak intensywnie analizowane jak wzrokowe. Funkcjonowanie wzroku i słuchu jest nawet modelowane matematycznie za pomocą takich kategorii, jak długość fal świetlnych czy akustycznych oraz częstotliwość ich drgań.

Mamy zatem do czynienia z sytuacją uprzywilejowania w świecie, w tym świecie mediów, dwóch zmysłów, zaś smak, węch i dotyk pozostają na obrzeżach naszej uwagi, chociaż odpowiadające im wrażenia też są powszechne.

W tekście uwaga zostanie skupiona przede wszystkim na zmyśle węchu, ale też na ściśle z nim powiązanym zmyśle smaku. Ich nieobecność w starych i nowych mediach związana, jak sądzę, głównie z możliwościami technologicznymi, czy też raczej ich brakiem w tym zakresie, skutkuje ważkimi konsekwencjami poznawczymi.

Proces komunikowania społecznego, jako niezwykle ważki dla funkcjonowania społeczeństw, utożsamiany był zasadniczo z kodami werbalnymi. Słowom czy 
to czytanym, czy to słyszanym - przypisywano znaczenie fundamentalne. Język pisany i mówiony jawił się jako jedyne skuteczne narzędzie wyjścia z pułapki kulturowego niezrozumienia, natomiast kody niewerbalne, takie jak: dotyk, zapach, smak, długo pozostawały na marginesie badawczej uwagi.

Naukowcy ustanowili komunikację niewerbalną przedmiotem swoich badań stosunkowo późno, bo dopiero w połowie minionego wieku. Jako cezura w podejściu do form komunikacji pozawerbalnej jest uznawany rok 1946, czyli data powołania ustawą Kongresu Stanów Zjednoczonych Instytutu Służb Zagranicznych. To w tym resorcie słuchacze dowiadywali się, że dźwięk i obraz to za mało, by wchodzić w satysfakcjonujące relacje społeczne. Do ich pogłębienia, poszerzenia przydatny, a wręcz konieczny jest na przykład zmysł powonienia, bowiem kultury pachną i mają smak.

Ekspozycja wzorku i słuchu sprawiła, iż zapachowi nie przypisuje się pierwszorzędnej rangi. Zapach jako zbyt ulotny i nieokreślony, niedający się mierzyć w takim stopniu jak dźwięk czy obraz, ustępował pola zmysłom bardziej trwałym i jednoznacznym. Medialną obecność zapachu w produkcjach filmowych należy uznać za skrajnie marginalną. Nie pachną filmy fabularne, nie pachną też filmy dokumentalne, także te o kulinariach bądź pokazujące lawendowe pola Prowansji i plantacje wanilii i goździków na Zanzibarze.

Namysł nad tą kwestią zostanie podjęty w kontekście dwóch teorii komunikowania społecznego - klasycznej już propozycji Marshalla McLuhana sprzed ponad pół wieku oraz powstałej na przełomie XX i XXI wieku kognitywnej teorii filmu.

\section{NOWE MEDIA WCIĄŻ STARE?}

„Technika to utrwalone społeczeństwo” - i chociaż nie są to słowa Marshalla McLuhana, a wybitnego francuskiego socjologa wiedzy Brunona Latoura, to w znacznym stopniu oddają one sens McLuhanowskiej idei techniki i technologii, a także mediów jako „przedłużenia człowieka”. Mimo iż McLuhan nie był socjologiem, za jego koncepcją komunikacji społecznej i teorią mediów stoi wyraźna wizja społeczeństwa, zgodnie z którą społeczeństwo nie jest ani bytem ponadjednostkowym, ani nie istnieje w jednostkach, ale pomiędzy nimi. Polega na wzajemnym oddziaływaniu jednostek, komunikowaniu się, interakcjach, współdziałaniu, konfliktach i dialogu. Tym, co wyróżnia człowieka na tle również komunikujących się zwierząt, jest świadomość owej komunikacji, dążenie do sposobów komunikowania się, które są coraz lepsze, coraz doskonalsze. 
Herbert Marshall McLuhan należał do nielicznego grona teoretyków komunikowania, którzy już w połowie zeszłego wieku formułowali trafne prognozy dotyczące wpływu mediów komunikacyjnych na przemiany psychospołeczne zachodzące w skali lokalnej i globalnej. Czy z dzisiejszej perspektywy, w tak odmiennej od obecnego środowiska komunikacyjnego infrastrukturze informacyjnej, prognozy te mogą jeszcze inspirować poznawczo współczesne pokolenie badaczy zajmujących się rolą mediów komunikacyjnych w przemianach cywilizacyjnych? Nawet pobieżna lektura prac McLuhana uprawnia do przyjęcia twierdzącej odpowiedzi na powyższe pytania.

Środki przekazu zawsze w jakiś sposób determinują kształt społeczeństwa i kultury w podobnym stopniu, w jakim determinują przekazywane komunikaty, informacje, wiedzę. Najwyraźniej teza ta została zaprezentowana na gruncie determinizmu technologicznego, którego McLuhan wydaje się najważniejszym przedstawicielem. Kanadyjski badacz, wychodząc od definicji pojęcia mediów komunikacyjnych, poprzez ich klasyfikację i opis funkcji, tworzy spójną koncepcję przemian cywilizacyjnych wywołanych sposobem przesyłania informacji. Według McLuhana społeczeństwa i poszczególne formacje cywilizacyjne różnią się między sobą przede wszystkim pod względem szybkości, z jaką odbywa się w ich granicach przepływ informacji. Jest to jednoprzyczynowe źródło przemian cywilizacyjnych.

U początków dziejów cywilizacji ludzkiej umieszcza plemienną wioskę, w której przepływ informacji dokonuje się na ograniczonej przestrzeni, a jego głównym instrumentem jest słowo mówione. Dalszy zaś rozwój środków przekazu i społeczeństw jest rezultatem stopniowej redukcji komunikatu oralnego (Jonscher, 2004, s. 44-50). Zdaniem McLuhana (2001) przekaźniki stają się swoistym „przedłużeniem człowieka”. Człowiek za sprawą techniki i technologii jest w stanie przedłużyć - niemal dosłownie - każdą część swojego ciała, a w miarę postępu również swoje zmysły (McLuhan, 2001, s. 217-219). Dowodził, że każda forma innowacji w mediach poszerza jakieś zdolności człowieka. Pismo i druk poszerzyły zdolności oka, koło stało się przedłużeniem możliwości, które daje stopa, telegraf i telefon zrewolucjonizowały zmysł słuchu, a obwody elektroniczne rozszerzyły zdolności centralnego układu nerwowego (McLuhan, 2001, s. 215).

Proponowany przez McLuhana rozwój społeczeństw dokonuje się w sposób szczególny, najpierw redukując polisensoryczność komunikatu oralnego, a potem usilnie do owej polisensoryczności dążąc. Czy z sukcesem?

Współczesne media elektroniczne sprawiają, że w dziedzinie komunikacji społecznej człowiek jest w stanie pokonywać zarówno czas, jak i przestrzeń. Niewątpliwie wprowadzają także powolne i trudno zauważalne zmiany w funkcjonowaniu ludzkiego umysłu, polegające między innymi na przesuwania obszarów 
tego, co społecznie uważa się za normalne. Za normalne na przykład współczesny człowiek uważa porozumiewanie się z innym człowiekiem przebywającym na drugiej stronie globu w czasie rzeczywistym. Czy miałoby to oznaczać, że dzięki mediom związanym z technologią elektryczną i elektroniczną ludzkość - co sugerował McLuhan - powraca do stanu plemiennego, a świat się kurczy do rozmiarów wioski? Czy technologie multimedialne sprawiają, że trudno jest dzisiaj mówić o uprzywilejowaniu któregoś ze zmysłów?

Sądzę, że na postawione wyżej pytania odpowiedź jest negatywna. Rozwój środków przekazu to, poza zmianą ich funkcji, roli, relacji nadawca-odbiorca, także, a może przede wszystkim, zmiany technologiczne, a więc doskonalenie jakości obrazu, jego wysokiej rozdzielczości, jakości dźwięku doprowadzonego bez mała do perfekcji. Wciąż jednak to rozwój odnoszący się do dwóch zmysłów wzroku i słuchu. Nawet jeśli uwzględnimy połączenie projekcji filmowej w 3D z realistycznymi efektami typu ruchome fotele, mgła, bańki mydlane, otrzymując w rezultacie 5D lub 6D, nowe media wciąż mają ograniczoną ofertę sensoryczną i w tym obszarze niewiele różnią się od swych poprzedników.

Projekcje filmowe to nadal olfaktyczne ułomności. Uzupełnijmy, iż olfaktyką nazywane są niewerbalne komunikacyjne funkcje zapachu. Projekcje filmowe bazują przede wszystkim na dwóch zmysłach, dając pierwszeństwo wzrokowi. Na prymarną pozycję tych zmysłów wskazuje między innymi fakt, że zwykle współczujemy niewidomym i głuchym, zaś utrata powonienia czy smaku nie jest postrzegana jako wyjątkowo dotkliwa. Zmysł węchu w swoistej hierarchii nie zajmuje zbyt wysokiej pozycji. Rzadko kto roni łzę nad dotkniętymi anosmią; rzadko kto w ogóle zna to słowo. A przecież zapach należy do najbardziej podstawowych i najwcześniejszych metod porozumiewania się. Skojarzenia zapachowe należą do najsilniejszych, jakie pamiętamy. Zapach wywołuje znacznie głębsze i silniejsze wspomnienie niż obraz.

Autorka książki Historii brudu, Katherine Ashenburg (2009), pisze, że nie pamięta obrazu swojej babci pochodzącej z Niemiec, lecz doskonale pamięta jej zapach: „Kojarzą się mi z nią dwie wonie. Po pierwsze, ciepły amalgamat drożdży i płótna: owijała w ścierki do naczyń i umieszczała na grzejnikach w jadalni ciasto na chleb, by wyrosło. Drugi zapach pochodził od niej samej. Gdy byłam dzieckiem, nigdy nie przyszło mi do głowy, by go opisywać albo rozkładać na czynniki pierwsze i zastanawiać się, skąd się bierze. Stanowił po prostu część mojej babci, którą kochałam, więc i jej zapach nigdy mi nie przeszkadzał” (s. 10). Jako dorosła i wychowana w sterylnej Ameryce wiedziała już, że ów drugi zapach to odór niemytego ciała i stęchłego potu. Ten zapach zapamiętała jako miły, a że sterylność nie pachnie, więc nie można jej pamiętać. 
Zastanawiające w tym olfaktycznym kontekście jest to, że intelektualnej uwadze wnikliwego i wszechstronnego badacza mediów, jakim był M. McLuhan, umyka tak istotny przekaźnik, jakim jest nos, jakim są receptory zapachowe. Próżno w jego błyskotliwych tekstach, pełnych paradoksów i aforyzmów, szukać odpowiedzi na pytanie, co w medialnym świecie jest przedłużeniem zmysłu powonienia. Deficyt w tym względzie tym bardziej dziwi, że bardzo kochał kino, cenił telewizję i dociekliwie je analizował. Nie wspominał jednak o tym, że przekaźniki nie znajdują ekwiwalentów dla wszystkich pięciu zmysłów.

Marshall McLuhan w filmie Woody'ego Allena Annie Hall zagrał samego siebie - guru ery telewizyjnej. Uważa się, iż pisał nawet w sposób telewizyjny odbiegający od naukowych dysertacji, daleko od standardów przyjętych w nauce. Jego teksty bardziej przypominały telewizyjny teledysk niż porządną akademicką rozprawę. Nie wykorzystał jednak ani swojej wiedzy, ani swojej sympatii do ekranowego przekaźnika, by podjąć refleksję nad jego sensoryczną ograniczonością i polisensorycznością zarazem.

Projekcje filmowe, i te z czasów McLuhana, i te współczesne, to wciąż olfaktyczne ułomności, zaburzające antropologię naszych zmysłów. Warto odwołać się do przykładów. Ile osób byłoby w stanie wytrwać do końca filmu Andrzeja Wajdy Kanał (1956), gdyby obrazom i słowom towarzyszył także zapach - woń kanałów, woń odchodów, woń ciał rozkładających się w sierpniowych upałach. Być może bodźce węchowe byłyby tak silne, że zdominowałyby inne zmysły.

Również filmy tzw. historyczne, gdyby dysponowały zapachowymi komunikatami, mogłyby zaburzyć widzom percepcję. Kostiumolodzy i scenografowie, zwykle skrzętnie dbający o detale, o każdy guzik królewskiej szaty, nie uwzględniają jednak ważkiego szczegółu, o którym rozpisuje się Georges Vigarello (1996) - nasi przodkowie nie myli się, od chłopa po króla. Aż do schyłku XVIII wieku unikali wody jak ognia (Vigarello, 1996, s. 67). Panowało mocno ugruntowane przekonanie, że płótno ma moc oczyszczającą i „myto się”, zmieniając koszule. Przez wiele wieków w Europie panowała zasada, według której zmiana bielizny powodowała, że brud zostawał usunięty. Bielizna miała przynosić skutek podobny do wody, jeśli nie lepszy. Koszula była gąbką.

W pałacach i zamkach, nie wspominając od pomniejszych domostwach, nie było kanalizacji i toalet, liczni mieszkańcy i nie mniej liczni goście nierzadko dawali upust swojej fizjologii po pałacowych kątach. Kiedy architekci minionych wieków rozważali umieszczenie w pałacach i zamkach łaźni na wzór starożytnych term, wpływowy budowniczy L. Savot stwierdził: „Możemy się bez nich obejść o wiele lepiej niż starożytni z powodu użycia bielizny, którą my posiadamy, a która służy nam obecnie do utrzymania w czystości ciała w sposób o wiele wygodniejszy, 
nie można było tego dokonać w łaźniach i łazienkach starożytnych, pozbawionych użytkowania i wygody, jaką daje noszenie bielizny” (Vigarello, 1996, s. 68). Znany zaś bajkopisarz francuski C. Perrault uzupełniał: „Od nas tylko zależy, czy zażywać będziemy kąpieli, jednakże czystość naszej bielizny i jej obfitość są więcej warte niż wszystkie kąpiele świata” (Vigarello, 1996, s. 68).

Jaki był olfaktyczny skutek takich praktyk higienicznych, nietrudno zrozumieć. Wszechogarniający smród rozkładających się odpadków, skwaśniałego wina, brudnej pościeli, ekskrementów i, w pierwszym rzędzie, fetor brudnych i spoconych ciał. Dla współczesnego nosa, nienawykłego do takich zapachów, nauczonego już we wczesnym procesie socjalizacji unikania tego rodzaju atrakcji węchowych, byłby to odór nie do zniesienia - odór, którego oszczędzają nam współczesne media.

Naturalnie można podać filmowe egzemplifikacje, które zmysł powonienia wprawiłby w dobry nastrój, gdyby odwoływały się także do nosa, a nie tylko do oka i ucha. W roku 2014 Lasse Hallstrom nakręcił film Podróż na sto stóp (2014) z Helen Mirren w roli głównej. To ekranowy przykład, kiedy kastracja powonienia okazuje się być poznawczym deficytem i ważkim niedostatkiem realizmu filmowego. Film traktuje o kuchni francuskiej, hinduskiej, o walce o gwiazdkę Michelin i o miłości. W zasadzie winno się go oglądać nosem i kubkami smakowymi, a nawet z zamkniętymi oczami. Przy jego odbiorze widz może doświadczyć czegoś na kształt poznawczego pogubienia, bowiem wszystko, co w nim ważne, jest de facto poza zmysłowym zasięgiem odbiorcy. Przy tego rodzaju produkcjach nabiera się przekonania, iż filmowy realizm wymaga polisensoryczności, w przeciwnym razie mamy do czynienia z czymś na kształt epistemicznej schizofrenii.

Filmowcy i miłośnicy kina próbują rozwiązać tę kwestię, proponując Kino Kulinarne, czyli połączenie seansów filmowych i inspirowanych ich tematyką kolacji przygotowywanych przez najlepszych polskich szefów kuchni. Takie rozwiązanie zaproponowali organizatorzy letniego festiwalu filmowego Transatlantyk, który rozpoczął się pokazem filmu Jedz i pij, mężczyzno i kobieto (1994) w reżyserii trzykrotnego zdobywcy Oscara - Anga Lee. Obraz opowiada historię Chu, emerytowanego szefa kuchni z Tajpej, który mieszka wraz z trzema córkami, a ich życie obraca się wokół celebracji niedzielnego, wyszukanego obiadu. Po projekcji został podany posiłek związany z klimatem filmu, przygotowany przez Wojciecha Modesta Amaro.

Można zasadnie przypuszczać, że po upływie kilkudziesięciu lat od upowszechnienia koncepcji McLuhana w zakresie alfabetyzmu mediów jest ona pewnym anachronizmem, bowiem kanadyjski naukowiec sformułował swoje - przyznać trzeba, bardzo trafne - spostrzeżenia na podstawie obserwacji telewizji lat 50., 60. 
i 70. ubiegłego wieku. W obecnej rzeczywistości medialnej możemy mieć kłopot z dopasowaniem tez Kanadyjczyka do telewizji i kina początku XXI stulecia. Nie oznacza to jednak, że myśl McLuhana przestała być atrakcyjna intelektualnie i inspirująca, jak chociażby ta już przywoływana, że media są przedłużeniem człowieka. W tym względzie wciąż poszukujemy medialnego przedłużenia dla receptorów węchu.

Kolejną propozycją, z perspektywy której warto spojrzeć na doznania olfaktyczne, jest kognitywna teoria filmu. Jak sama nazwa wskazuje, teoria ta bazuje na osiągnięciach kognitywistyki - dziedziny wiedzy zajmującej się badaniem procesów poznawczych. Nie wprowadza ona nowych pojęć, czerpiąc z repertuaru terminologicznego innych nauk, np. psychologii i filozofii. Najogólniej mówiąc, kognitywna teoria filmu zwraca uwagę na procesy zachodzące przy odbiorze dzieła filmowego, nie zaś tylko na ich efekt, co stwarza ciekawą perspektywę badawczą. Inaczej rzecz ujmując, można powiedzieć, iż teoria ta zajmuje się tym, co widz robi z filmem, aby go zrozumieć.

Podejście do dzieła filmowego w tej teorii ma charakter neoformalny, czyli film traktowany jest jako dzieło artystyczne podlegające kryteriom estetycznym. Natomiast po stronie odbiorcy szczególnie istotny jest sposób przetwarzania informacji. Zasadą, która porządkuje relacje powstające między filmem a widzem, jest zasada peryferycznej aktywizacji wyobraźni widza. Polega ona na tym, że z jednej strony widz identyfikuje się, odczuwa emocje oraz ma takie same doświadczenia poznawcze jak bohater filmu, a z drugiej strony cały czas pozostaje na pozycji obserwatora. To powoduje, że wyobraźnia widza może pracować w trybie centralnym - stany psychiczne odbiorcy nakładają się z tymi przeżywanymi przez fikcyjnego bohatera. Ale wyobrażenia odbiorcy mogą mieć także charakter acentralny - jako obserwator widz może martwić się o bohatera, może być mu przykro z powodu jego niepowodzeń (Ostaszewski, 1999, s. 47). Kognitywna teoria filmu zakłada dalej, że widzowi w stosunku do przekazu filmowego przyświecają takie cele, jak w rzeczywistych sytuacjach. A więc chce zrozumieć akcję, motywy leżące u podłoża zachowań bohaterów, a także kontekst społeczny, historyczny i kulturowy. Taką postawę widza można powiązać z rozwiązywaniem problemów. Oznaką poradzenia sobie z dylematem będzie zrozumienie filmu, czy też inaczej - nadanie znaczeń obserwowanym wydarzeniom.

Ostatnie ogólne założenie omawianej teorii wiąże się z uznaniem innego niż tradycyjny model komunikacji. Koncepcja ta zakłada bowiem, że znaczenie nie jest dekodowane przez odbiorcę, ale raczej jest wnioskowane na podstawie danych, wskazówek, których film mu dostarcza. Ten model komunikacji określany jest 
mianem implikacyjno-inferencyjnego i zakłada znacznie bardziej wytwórczą aktywność jednostki (Ostaszewski, 1999, s. 72).

Można zatem powiedzieć, że to, jaka będzie reprezentacja psychiczna przekazu filmowego widza, zależy przede wszystkim od jego zaangażowania, od tego, jakie aspekty własnych doświadczeń wykorzysta do interpretacji filmowej sytuacji i jak przetworzy docierające do niego dane. Zrozumienie filmowej rzeczywistości przez odbiorcę nie musi w związku z tym odkrywać znaczeń, które chciał zawrzeć w dziele jego twórca. Człowiek posługuje się bowiem własnym i swoistym „szkłem powiększającym”.

Jako że kognitywna teoria filmu jest złożona i wielowątkowa, uwaga zostanie skupiona na jednym jej aspekcie - wyobrażeniach. Wyobrażenia to obrazy umysłowe podobne do postrzeżeń, ale obecne bez bodźców fizycznych (Mach, 2009, s. 147). Wyobrażenia tym różnią się od postrzeżeń, że można je przywołać w dowolnym momencie, niezależnie od materialnej obecności obiektu. Dodajmy, że postrzeżenia (percepcja) i wyobrażenia to różne procesy umysłowe, jednakże w dwóch trzecich angażujące te same obszary mózgu (Mach, 2009, s. 112-113). Zgodnie z kognitywną teorią filmu w czasie projekcji np. W ciemności (2011) Agnieszki Holland wyobrażamy sobie (jeśli w ogóle) smród kanałów miejskich, ale go nie doświadczamy. Formy niewerbalne, takie jak smak, zapach, w produkcjach filmowych bazują na wyobrażeniach. I tu pojawia się ważkie pytanie o naturę owych wyobrażeń: od czego wyobrażenia zależą, co je warunkuje? W historii badań nad architekturą funkcjonalną umysłu, czyli funkcjami umysłu przetwarzającymi informacje, wyraźnie zarysowały się dwa konkurencyjne stanowiska. Pierwsze, określane jako reprezentacja analogiczna, zgodnie z którym wyobrażenie odwzorowuje strukturę czegoś, co reprezentuje, czyli zachodzi strukturalne podobieństwo między strukturą reprezentacji (nośnika) a strukturą desygnatu reprezentacji.

Drugie nazywane jest reprezentacją symboliczną, tu relacja podobieństwa strukturalnego nie jest istotna, relacja między wyobrażeniem a desygnatem jest arbitralna, lecz podlega regułom logicznym. Na przykład jeśli wiem, jaki zapach ma niesprzątana toaleta, to w oparciu o zasady logiki mogę wnioskować i mieć wyobrażenie smrodu miejskich kanałów.

Sporu między obiema koncepcjami, jakkolwiek wartościowego poznawczo, nie ma potrzeby przywoływać, poprzestańmy zatem na rozstrzygnięciach. Oto kognitywiści mówią o tzw. dyspozycji relacyjnej, to znaczy, że natura wyobrażeń wiąże się bezpośrednio z doświadczeniami percepcji. Widz wykorzystuje więc posiadaną wiedzę i tworzy jej reprezentacji w umyśle (Ostaszewski, 1999, s. 94). W praktyce, także filmowej, należałoby to tłumaczyć, że jeśli osoba nigdy nie 
wąchała np. duriana, to oglądając dokument filmowy o tajskim bazarze nie będzie miała w tym względzie żadnych zapachowych wyobrażeń. Istnieje bowiem relewancja między wyobrażeniem a percepcją. Percepcja nie jest li tylko ułatwieniem przy wyobrażeniu, ale jest warunkiem koniecznym. W konsekwencji daje to epistemiczną sytuację, w której ten sam film dla różnych podmiotów może się sytuować w różnych miejscach na kontinuum rozciągniętym między fikcją a realizmem.

Należy wyraźnie podkreślić, że relewancja nie ma nic wspólnego z tzw. intuicyjną znajomością fizyki świata. Wiedza przekazana inaczej niż przez postrzeżenia jest w tej sytuacji niewystarczająca. Tym bardziej że receptory węchowe są wieloaspektowo zdominowane, a jedną z ważniejszych determinant jest temperatura, o czym zwykle zapominamy. Receptorom węchowym w jamie nosowej nie jest obojętne, czy na zewnątrz panuje upał, czy mróz. Wraz z wdychanym powietrzem do nosa dostają się lotne substancje zapachowe. Ich molekuły osiadają na receptorach węchowych, a te informacje o wykrytych aromatach natychmiast przysyłają do mózgu. Zimą koncentracja wielu wonnych substancji w powietrzu spada. W niskich temperaturach unoszą się one i wędrują niechętnie, natomiast przy wysokich krążą w powietrzu o wiele szybciej.

Z drugiej strony Pamela Dalton, wybitna neurobiolożka z amerykańskiego Monell Chemical Senses Center w Filadelfii, podkreśla jednak, że zapach to jedno, a emocje z nim związane to drugie, poznawcze funkcje wrażeń zapachowych są więc wyjątkowo złożone. Badaczka wielokrotnie zaznacza, że aspekty kognitywne, jak np. uprzednie doświadczenia czy też kontekst, wpływają na percepcję olfaktyczną w stopniu nie mniejszym niż sam zapach (Dalton, 1996, 2000). Dlatego jeśli ktoś lubi zimę, to mroźne powietrze skojarzy z czymś przyjemnie orzeźwiającym. Kto jej nie lubi, ten żadnej przyjemnej woni nie poczuje.

\section{ZAMIAST KONKLUZJI}

Powyższe rozważania mogą być odczytane jako swoisty lament nad brakiem zapachowych atrakcji w produkcjach filmowych czy też ich niedostatkiem. Nie to jednak było głównym zamysłem, jakkolwiek ich obecność radykalnie zmieniłaby percepcję odbiorcy, zaś uaktywnienie wszystkich zmysłów w czasie filmowego seansu byłoby doświadczeniem być może skrajnym, choć nie do końca nowym.

Powołany do życia blisko wieku temu - w 1931 roku - przez Aldousa Huxleya Nowy wspaniały świat jest światem spełnionej rzekomo szczęśliwości. Po tak długim czasie, jaki upłynął od chwili stworzenia tej dość już anachronicznej wizji społeczeństwa organizowanego za pomocą metod biologicznych, zasadność 
odwołania się do tej książki może wydać się wątpliwa. Powieść Huxleya nie stanowi jednakże tylko antywellsowskiej wypowiedzi w sprawie tragicznych skutków tryumfu nauki i techniki. Uniwersum tego dzieła przekracza daleko wszelkie doraźne - także polityczne - cele, którym przed laty mogło ono służyć.

Ta książka, jak sądzę, swoją aktualność zyskuje poprzez dowiedzenie, że logikę rozwoju cywilizacji przemysłowej, w tym cywilizacji mediów, warto zgłębiać nieustannie. A nieodparty charakter tej logiki zdaje się nas przekonywać, że społeczne spełnienie może przybierać zgoła nieoczekiwane formy. W świecie skonstruowanym przez Huxleya jako antyutopia wszystkie zmysły są wykorzystywane do przejęcia pełnej, totalitarnej kontroli nad jednostką. Także smak i zapach spełniają w tym procesie ważkie funkcje. Na przykład kilkuletnie dzieci mają kojarzyć przyjemny zapach czekoladowego eklera ze śmiercią starych (czytaj - zbędnych) ludzi, jako coś przyjemnego i pożądanego. Huxley (2001, s. 196-197) nazywa to uwarunkowaniem tanatycznym. Współczesne osiągnięcia filmowych technik sensorycznych u wspomnianego pisarza zwą się swojsko czuciofilmem i skutecznie służą odbieraniu człowiekowi kontroli nad jego emocjami (Huxley, 2001, s. 164).

Za sprawą czuciofilmów, kiedy widz doświadcza identycznych przeżyć co aktorzy, dokonywana jest monstrualna manipulacja świadomością jednostek. Utrata kontroli nad własnymi zmysłami jest utratą władzy i panowania nad samym sobą.

Rodzi się zatem, jak mniemam, całkiem zasadne pytanie - czy aby niewinne produkcje filmowe typu 3D, 5D, 6D nie są przedsionkiem do nowego wspaniałego świata w huxleyowskim stylu? A może te niezagospodarowane przez media zmysły, jak smak i zapach, to nasze ostatnie enklawy wolności w zmediatyzowanym świecie?

\section{Bibliografia}

Ashenburg, K. (2009). Historia brudu. Tłum. A. Górska. Warszawa: Bellona.

Dalton, P. (1996). Odor Perception and Beliefs about Risk. Chemical Senses, 21(4), s. 447-458. https://doi.org/10.1093/chemse/21.4.447.

Dalton, P. (2000). Fragrance Perception: From the Nose to the Brain. Journal of the Society of Cosmetic Chemists, 51(2), s. 141-151.

Hopfinger, M. (2003). Doświadczenia audiowizualne. O mediach w kulturze współczesnej. Warszawa: Sic!.

Huxley, A. (2001). Nowy wspaniały świat. Tłum. B. Baran. Warszawa: Porozumienie Wydawców.

Jonscher, C. (2004). Życie okablowane. Kim jesteśmy w epoce przekazu cyfrowego. Tłum. L. Niedzielski. Warszawa: Muza. 
Mach, E. (2009). Analiza wrażeń i stosunek sfery fizycznej do psychicznej. Tłum. M. Miłkowski. Warszawa: Wydawnictwo Naukowe PWN.

McLuhan, H.M. (2001). Kultura jest naszym biznesem. W: E. McLuhan, F. Zingrone (red.), McLuhan. Wybór tekstów. Tłum. E. Różalska, J.M. Stokłosa. Poznań: Zysk i S-ka.

McQuail, D. (2007). Teoria komunikowania społecznego. Tłum. M. Bucholc, A. Szulżycka. Warszawa: Wydawnictwo Naukowe PWN.

Ostaszewski, J. (1999). Film i poznanie: wprowadzenie do kognitywnej teorii filmu. Kraków: Wydawnictwo Uniwersytetu Jagiellońskiego.

Vigarello, G. (1996). Czystość i brud. Higiena ciała od średniowiecza do XX wieku. Tłum. B. Szwarcman-Czarnota. Warszawa: W.A.B. 